NBER WORKING PAPER SERIES

MANAGING THE U.S. GOVERNMENT DEFICI'T
IN THE 1980s

Benjamin M. Friedman

Working Paper No. 1209

NATIONAL BUREAU OF ECONOMIC RESEARCH

1050 Massachusetts Avenue

Cambridge, MA 02138

October 1983

The research reported here is part of the NBER's research program in Financial Markets and Monetary Economics and project in Government Budgets. Any opinions expressed are those of the author and not those of the National Bureald of Economic Research. 
NBER Working Paper $\# 1209$

October 1983

Manaing the U.S. Government Deficit in the 1980 s

ABSTRACT

In the absence of major policy changes, federal government budget deficits will probably constitute a serious impediment to any increase in the U.S. economy's net investment rate, and may even depress the investment rate still further, during the latter 1980s. The U.S. Government's outstanding debt is now rising sharply in relation to gross national product, and, under either current legislation or the budget policies proposed by the Reagan Administration, it will continue to do so. This sustained upward movement of the government debt ratio will be unprecedented in U.S. peacetime experience. Because government debt and private-sector debt have historically moved inversely in relation to gross national product in the united states, a rising government debt ratio over time implies a sustained contraction of private debt relative to the economy's size. This reduction in the private sector's relative debt position in turn implies a constriction of its ability to finance investment in net new capital formation.

\author{
Benjamin M. Friedman \\ Harvard University \\ Department of Economics \\ Littauer Center 127 \\ Cambridge, MA 02138 \\ (617) $495-4246$
}


The prospect of a large and persistent government budget deficit during the balance of the 1980s has become the focus of intense public policy concern in the united states. This widespread anxiety has stemmed from the experience of actually realized U.S. Government deficits in the early years of the decade, as well as from the growing awareness of a persistent imbalance between the government's revenues and expenditures. The federal deficit in the 1983 fiscal year reached a peacetime record level, not just in absolute dollars but in relation to the size of the U.S. economy. Moreover, it has become apparent that, under the policies in effect as of the time of writing, the deficit will not shrink over time, even as the economy recovers from the severe effects of the two business recessions that marked the onset of the 1980s. It is also now apparent (if it ever was not) that such politically popular actions as cutting income tax rates or trimming "wasteful, fraudulent and abusive" elements of government spending will not eliminate the deficit either.

one of the most important reasons why this large and growing government deficit represents a cause for alarm is its negative implications for the economy's ability to undertake fixed capital formation and thereby to achieve rapid growth of productivity and, ultimately, the population's standard of living. Capital formation is sufficiently central to the economy's development prospects overall, and the potential links between it and government saving or dissaving are sufficiently important, that the threat to capital formation stands out as one of the leading elements underlying 
the concern that the spreading realization of the deficit problem has prompted.

The connection to capital investment is hardly the only reason why numerous diverse constituencies have reacted sharply to the emerging deficit prospects, of course. Fears of a re-acceleration of price inflation, for example, stand out prominently in this regard. Although it is strictly correct, in an analytical sense, to distinguish between the respective inflationary consequences of government debt issues and money creation, for practical purposes it is naive to suppose that the political and societal pressures which lead to large deficits over many years will not also affect the posture of monetary policy. For reasons more political than economic, therefore, a decade marked by continuing large government deficits is also likely to be an inflationary era. The primary focus of this paper, however, is the implication of a continuing deficit for the U.S. capital formation process.

The role of physical capital formation in enhancing productivity has always been an elusive subject for economists. At an abstract level the contribution of plant and equipment to workers' ability to generate output appears obvious enough. Yet accounting for historical productivity growth in any precise way has proved problematical, and the extra productivity growth likely to result from additional capital investment in the future is correspondingly difficult to quantify.

More specifically, what is clear is that since the late 1960 s the U.S. economy's net capital formation rate has fallen by almost any measure. After allowance for depreciation and obsolescence (but not for investment in pollution control), the united states devoted an average $3.5 \%$ of its gross national product to increasing its net stock of fixed 
nonresidential capital during 1961-70, but only 3.0\% during 1971-80 (and even less during the subsequent recession years). As a combined result of the decline in the capital formation rate and the unusually large growth of the labor force which took place over these same years, the amount of capital per worker in the U.S. economy's private sector grew by $3.2 \%$ per annum on average during 1961-70, but only $1.3 \%$ per annum during 1971-80. At the same time, the economy's productivity growth slowed from $2.8 \%$ per annum on average during 1961-70 to only 1.4\% per annum during 1971-80..$^{1}$ What is unclear is how much faster productivity would have grown if capital formation had not slowed (but other adverse developments, like energy price increases and business recessions, had occurred as they did historically). What is also unclear, therefore, is what marginal impact on productivity growth during the balance of the 1980 s would follow from, say, a restoration of the net nonresidential capital formation rate to $3.5 \%$ of gross national product as in the 1960 s, versus a continuation of the $2.4 \%$ rate realized in $1981-82$ (or possibly even lower). ${ }^{2}$ The potential role of a greater capital stock in spurring aggregate productivity growth is not the only rationale underlying the widespread support for an increased U.S. capital formation rate during the 1980 , but the other dimensions of the subject are, if anything, even harder to quantify. Familiar questions like whether the United States should continue to have a major position in the world steel industry, or whether the nation should move more vigorously toward energy independence, or whether it should pursue a sharply accelerated shift of production into "high technology" areas - each an interesting and important issue on its own - are also all questions about the magnitude and the composition of the economy's capital formation. In addition to whatever more specific public policy 
measures may help to determine the resolution of each of these issues, the general economic and financial environment that either fosters or impedes fixed capital formation overall will importantly affect all of them. The stance of fiscal policy, as summarized in part by the path of the U.S. Government's budget deficit, will in turn be a central element importantly shaping that environment.

The object of this paper is to assess the prospects for this interaction between capital formation and the government deficit in the United states during the remainder of the $1980 \mathrm{~s}$, and in particular to consider potential budgetary choices from the perspective of their likely effect on the economy's capital formation rate. To anticipate, the paper's examination of the most likely prospects for this interaction indicates that, in the absence of new policy directions and initiatives, the macroeconomic effects of U.S. fiscal policy will probably place unprecedentedly severe strains on the economy's ability to undertake new capital formation in the medium-run future. By contrast, an alternative fiscal policy stance consistent with maintaining or even enhancing the nation's capital formation rate would probably require a combination of individually important changes. Section I reviews, with specific reference to prospects for the 1980 s, the economics of the connection between government deficits and private capital formation. Section II builds on this analysis to consider specific policies for limiting the deficit to a level consistent with preserving capital formation. A novelty of the analysis here is its use of the ratio of the government's outstanding debt to the economy's gross national product as a benchmark measure summarizing the implications for private financing, and hence for private capital formation, of any given deficit path through time. Section III extends the analysis to consider 
two potentially important aspects of fiscal policy not directly incorporated within the narrow lens provided by the overall budget deficit per se, including the composition of the government's spending and the composition of its liabilities. Section IV briefly summarizes the paper's major conclusions and policy recommendations. 
I. The Interaction Between Capital Formation and Government Deficits

The U.S. economy has traditionally allocated about one-sixth of each year's total output to investment for the future. Considered in isolation, without any benchmark reference points, this fraction appears neither large nor small. Most families would be pleased if they could set aside a sixth of their incomes to provide for their future needs, and few manage to do so. The saving problem from the overall economy's perspective is not the same as the saving problem from the perspective of an individual family, however, since the economy must be self-sufficient in ways that few families ever are. In comparison with an individual family, the aggregate economy has not only a richer set of opportunities to save but also a broader range of claims on whatever saving it does.

Table 1 summarizes the experience of the U.S. economy in this regard since 1955 by showing the relationship among the main elements of its saving and investment, stated throughout as percentages of gross national product. The data in the table condense the 1956-80 experience into averages for successive five-year periods, but show the more recent experience during 1981 and 1982 separately. The upper part of the table details the economy's sources of gross saving, while the lower part relates this saving to its use for gross investment (which equals gross saving except for statistical discrepancies).

What is most striking about the economy's saving behavior as shown in Table 1 is, first, the relative lack of variation in the total saving experience over the past quarter century and, second, the sharp departure from prior experience associated with the large federal government deficit in 1982. Contrary to the usual impression of declining private saving, the U.S. economy's gross private saving rate has shown little variation 


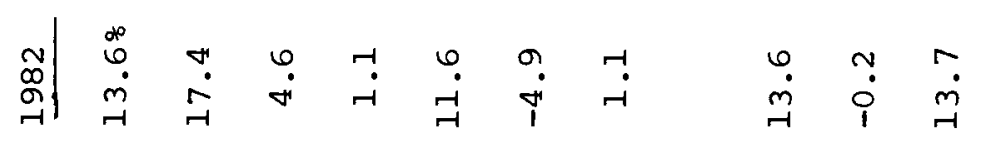

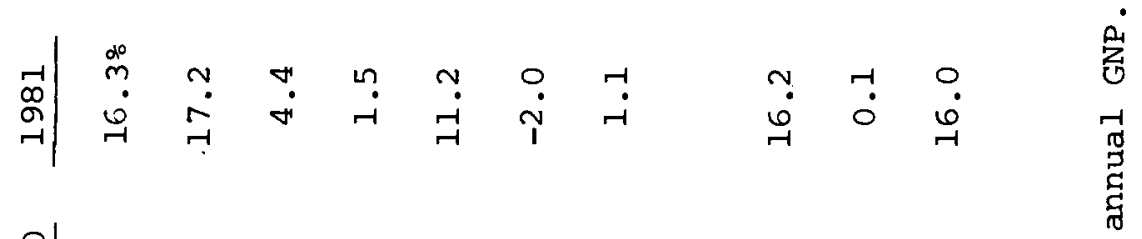

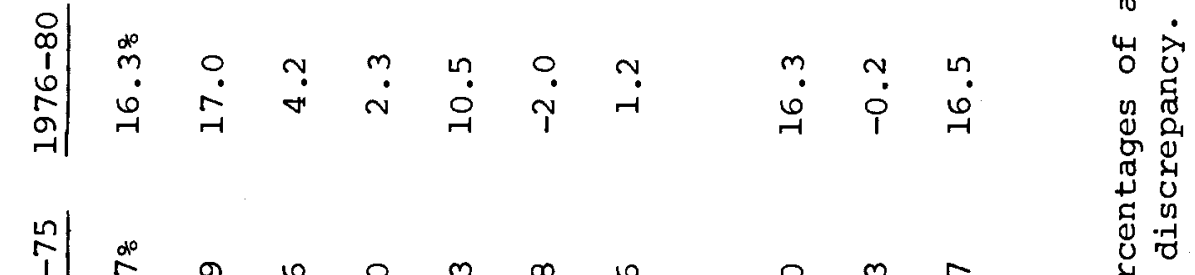

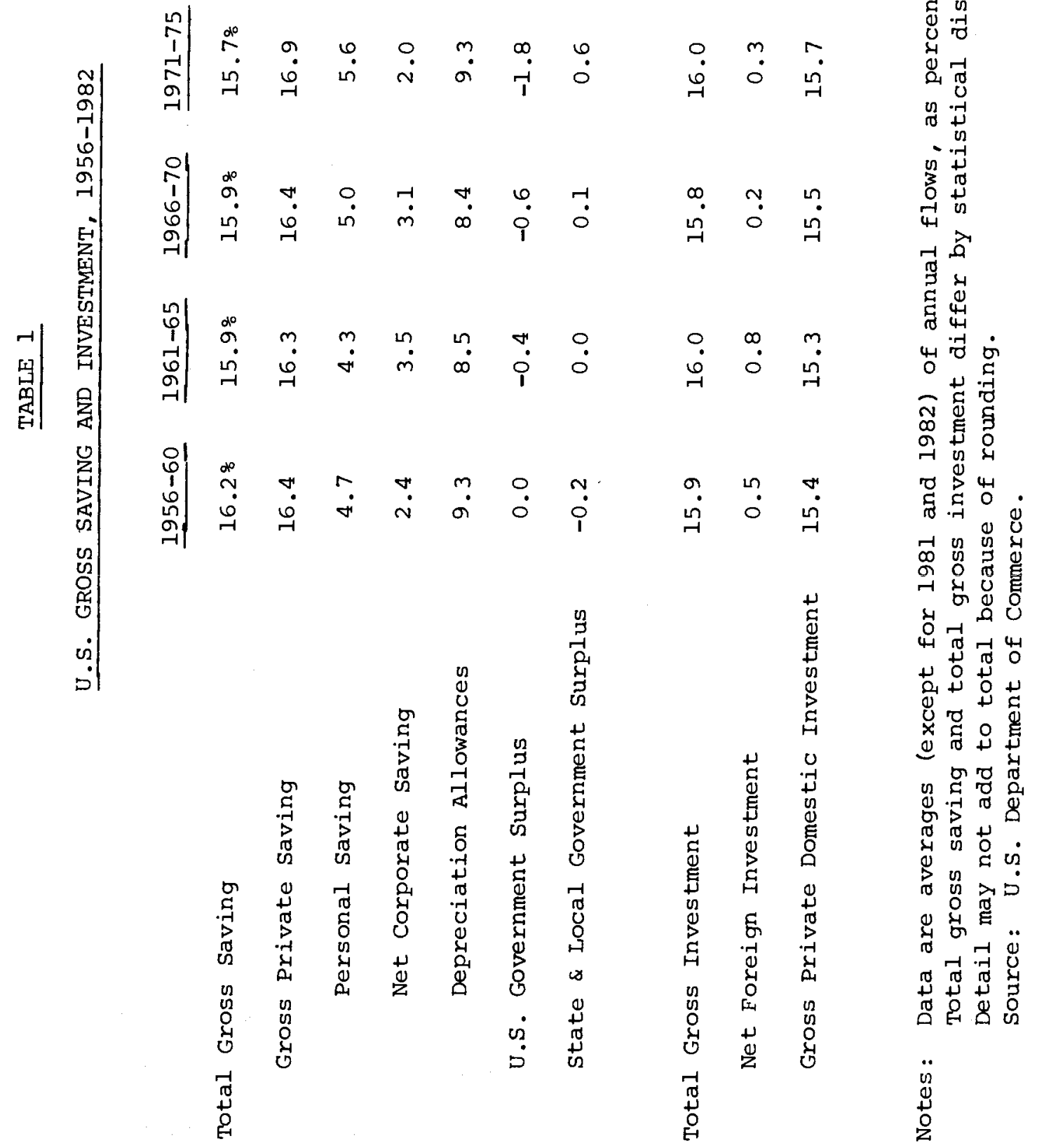


in recent decades, hovering closely around an average $16.7 \%$ of gross national product. Within the total of gross private saving, personal saving has remained equally steady around an average $4.7 \%$ of gross national product. The retained earnings of corporate businesses, measured net of taxes, depreciation and artificial inventory profits due to the use of first-in-first-out accounting methods, have declined sharply relative to gross national product during the last decade, but the relative growth of depreciation allowances (adjusted to reflect true economic depreciation) has more than offset that decline. In sum, the economy's gross private saving has actually grown slightly in comparison to its total output. Because more than all of the increase has consisted of depreciation, however, the economy's net private saving (equal to gross private saving less depreciation) has declined in relative terms.

The private sector, including both households and businesses, is not the only source of saving. The economy's total saving consists of private saving plus the saving - or, importantly, the dissaving of government. In large part because of the surpluses associated with funding the pensions of teachers and other employees, state and local governments have increasingly added to total gross saving since the mid $1960 \mathrm{~s}^{3}$ By contrast, the federal government's budget deficit has grown steadily over this period - from a balanced budget on average during the 1950 , to average deficits of $0.5 \%$ and $1.9 \%$ of gross national product in the 1960 s and 1970s, respectively, to a peacetime record 4.98 of gross national product in 1982 . This growth of dissaving by the federal government has more than balanced the growth of saving by state and local governments, so that the economy's total saving has not kept pace with its private saving. In 1982 the total gross saving rate was at its lowest point since 
World War II. Because saving is what finances investment, so too was the total gross investment rate.

Although the U.S. economy's total gross investment rate has shown little change (actually a small increase) in recent years, except for 1982, what presumably matters for productivity growth is not total investment but only the additions to productive plant and equipment - and, moreover, not gross investment but investment net of depreciation. New installations that merely replace earlier ones which have worn out through time and usage, or which have become obsolete as technologies change, do not represent further accumulation of capital. In the sense that matters here, therefore, the part of saving offset by depreciation correspondingly does not represent a genuine setting aside of the economy's resources to provide for its future. What matters instead is net saving and net investment.

Table 2 indicates the composition of gross private domestic investment, as shown in Table 1 , among business plant and equipment, residential construction, and inventory accumulation. In addition, for the plant and equipment component the table shows the mix of depreciation and net investment comprising the gross investment total. 4 Except for the early 1960 s and again in 1982, gross investment in plant and equipment has now shown a steady increase in relation to gross national product for several decades. Once again, however, more than all of this long-term increase has consisted of a relative growth of depreciation allowances, due to the economy's rising overall capital intensity and to the progressive change in the composition of the capital stock away from (longer-lived) plant toward (shorter-lived) equipment. ${ }^{5}$

By contrast, net investment in plant and equipment increased sharply 


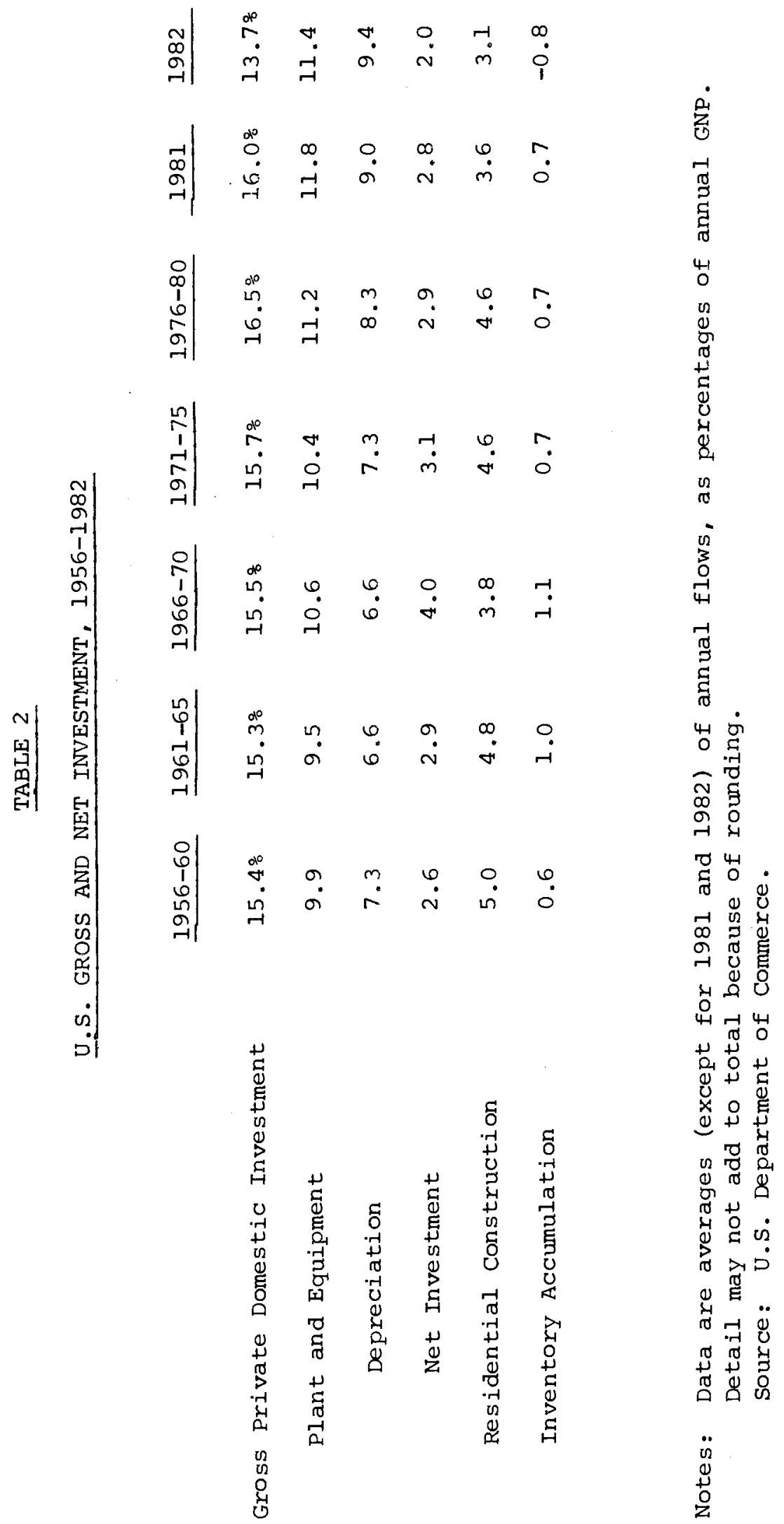


as a share of gross national product during the 1960 s but then fell just as sharply during the 1970s. The $2.0 \%$ recorded in 1982 closely approached the lowest net investment rate for plant and equipment that the U.S. economy has experienced since World War II (1.8\% in 1958). Moreover, this deterioration in the economy's net investment in relation to gross national product has also corresponded to a deterioration in comparison to the existing capital stock. From a peak of $4.7 \%$ per annum on average during 1966-70, the growth rate of the U.S. economy's net stock of private non residential capital declined to $3.9 \%$ per annum on average during 1971-81, and only $2.4 \%$ in 1982 .

In the context of this deteriorating investment performance, the immediate source of current alarm about the federal government's budget is the prospect that, even after the economy completes its recovery from the 1980 and 1981-82 business recessions, the federal deficit in relation to gross national product will not return even to the level of the 1970 s, much less to the more nearly balanced budget experience of the 1950s and 1960s. Without policy changes, the Reagan Administration's 1983 estimates indicate an increase in the total federal deficit (including a small amount of "off-budget" outlays) to $7.1 \%$ of gross national product in each of the 1983 and 1984 fiscal years, followed by a decline only to $6.4 \%$ of gross national product in fiscal year 1988 despite a projected recovery to a $6.5 \%$ unemployment rate in that year. ${ }^{6}$

The likelihood of large and growing government deficits in the remainder of the 1980s therefore calls into question the economy's ability to achieve significant progress in increasing its net capital formation rate, and even raises the prospect that the decline shown in Table 2 may continue still further. Although the Economic Recovery Act of 1981 included 
several measures intended to stimulate private saving, the data shown in Table 1 suggest that the share of private saving in the U.S. economy exhibits only limited responsiveness. More sophisticated econometric investigations typically confirm this casual impression. ${ }^{7}$ Moreover, even if these tax measures succeeded in increasing the gross private saving rate by fully one-half - that is, from the historical average $4.7 \%$ of gross national product to an unprecedented $7.1 \%$ - that still would not be nearly sufficient to fund the projected increase in the federal deficit and also finance private capital formation even at its recently depressed pace.

What is the economic process by which growing federal budget deficits can so impair the economy's ability to undertake private capital formation? The answer depends, in the first instance, on whether the government deficit itself is the result of an active fiscal policy that sets the government's expenditures in excess of even the level of revenues it would achieve if the economy were operating normally or, alternatively, the result of a depressed economy. In addition, the answer depends importantly on what posture monetary policy assumes in conjunction with fiscal policy. Table 3 presents data comparing the actual federal government budget surplus or deficit realized during the past quarter century to the surplus or deficit that would have ensued, under unchanged legislation, if the economy had been at "high employment." The upper part of the table compares the actual and hypothetical budget totals in dollar magnitudes. The lower part compares the actual budget outcome measured as a percentage of actual gross national product, as shown in Table 1 , to the corresponding high-employment total measured as a percentage of the economy's potential gross national product. 


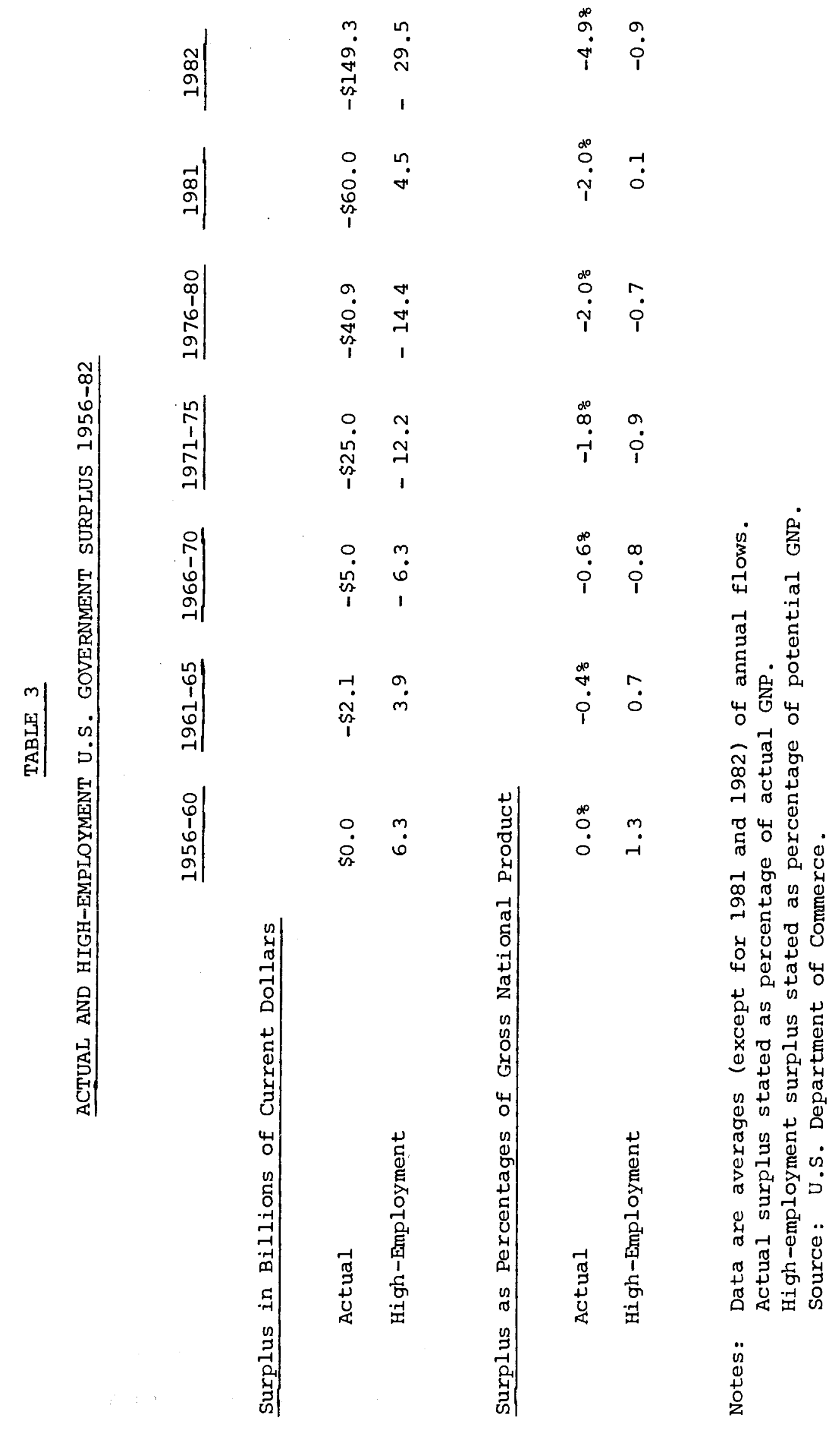


Since 1955 more than three-fourths of the cumulated actual federal deficit has merely reflected the smaller government revenues that accompany reduced incomes, together with the additional government spending intended to supplement reduced incomes, in periods of weak overall economic activity. The distinction between active and passive deficits was especially important in 1981 and 1982, the years of what was by many measures the most severe business recession since the 1930s. The passive response of revenues and spending accounted for more than all of the realized federal deficit in 1981, and for more than four-fifths of the realized deficit in 1982 .

When a government deficit emerges as a passive result of a weakened economy, it carries little if any indication that fiscal policy is retarding private capital formation. Such a passive deficit is simply the mirror image of the excess of private saving that always accompanies (in some senses, defines) a recession in the first place. ${ }^{8}$ For this reason it is difficult to blame the weakness of U.S. capital formation in 1981 and 1982 on the enlarged federal deficit. The more plausible interpretation of the experience of the past two years is, instead, just the opposite - that the weakness of business investment, by contributing to the severity of the recession (while also being affected by the recession, of course), caused the deficit to be larger than it would have been otherwise. The problem confronting U.S. capital formation during the balance of the 1980 s is different, however. If the deficit were merely passive, it would shrink and ultimately disappear in the course of the business recovery. Instead, nearly all estimates indicate that without policy changes the deficit will grow larger. Over time, therefore, the growing deficit will increasingly represent not a passive but an active deficit. In contrast to 1982 , when less than $20 \%$ of the deficit was active in this 
sense, the Reagan Administration has estimated that even by 1984 more than $70 \%$ of the deficit will be its active component, and by 1987 the active component will be more than $90 \%$.

When the government runs a deficit even though the economy is fully employed, the most basic reason why private capital formation suffers is that the excess of government spending over government revenues represents a net claim on the economy's real resources. Government purchases of goods and services - airplanes for the military, for example, or bridges and highways - clearly constitute uses of the economy's productive capacity directly by the government. Government transfer payments - Social Security benefits, for example, or food stamps - facilitate uses of the economy's productive capacity, typically for consumption spending, not directly by the government but by the recipients of these transfers. To the extent that the government raises tax revenues commensurate with its spending, it draws its claims on the economy's resources by simply taking income (or profits) away from other potential claimants. The total claim on resources represented by the government's spending does not disappear just because the government runs a deficit, however. To the extent that the government's revenues fall short of its expenditures, so that the government must borrow to cover its deficit, the process of reducing the private sector's claims on resources is indirect, relying not. on coercion but on market pressures. ${ }^{9}$

The nature of the market process by which the financing of a government deficit reduces the private sector's use of resources depends in turn on the posture of monetary policy. If monetary policy accommodates the deficit, in effect monetizing the newly issued government debt, ${ }^{10}$ then the resulting monetary growth when the economy is already fully employed will 
typically lead to price inflation, which reduces the private use of resources by eroding people's purchasing power. In this case the government deficit in effect claims resources that would have been used for consumption spending, especially by those whose incomes and assets are most vulnerable to inflation. $^{11}$ The course of U.S. monetary policy since the late 1970 s makes such an outcome appear unlikely, however, and it is presumably undesirable in any case. Once the economy has recovered from the recession, continued accommodation of a sustained government deficit would only create anew the inflationary spiral which led policy makers to take actions that produced the recession in the first place.

If monetary policy does not accommodate the government deficit, then the sale of government debt to the general public constitutes a direct absorption of private saving and therefore reduces the amount of that saving left to finance private investment. Here the market mechanism that pre-empts the private sector's use of the economy's resources is not price inflation but high interest rates. Since no one is forced to buy government securities, additional sales of debt to finance the government's deficit will be possible only if the government raises the interest rate it pays on its debt. Once the government pays a higher interest rate, however, private borrowers must also pay higher interest rates if they are to sell their debt, but not all private borrowers will be willing to do so. Some business firms will find that a planned investment opportunity is no longer profitable at the new, higher financing cost, just as some families will find that a planned new home or new car purchase is no longer affordable at the new, larger monthly payment. Interest sensitive private spending, including physical capital formation, will decline, and in the end the economy's total investment will equal the deficit-reduced total saving. 
This effect of government deficits operating through higher interest rates is always present, whether or not the economy is operating at full employment; but when the economy is not fully employed other effects are at work which may be equally or even more powerful. When the government runs a larger deficit, it does so because it is spending more itself, or because it is making larger transfer payments, or because it is collecting less taxes. Any or all of these actions increase the demand for goods and services, either directly in the case of the government's own spending or indirectly in the case of the spending of transfer recipients and taxpayers. The overall effect on total demand is the net of the negative impact on interest-sensitive spending and the positive impact of the actions that immediately account for the deficit.

Although there are some conditions under which the negative effects on spending due to higher interest rates would outweigh the positive effects that are more obviously tied to the government's spending and taxing, ${ }^{12}$ it is highly unlikely that those conditions even roughly describe the U.S. economy. Government deficits caused by an active fiscal policy that is increasing government spending and/or reducing taxes therefore raise the overall level of economic activity, at least as long as there is room left to raise it. Further, if accelerator effects are sufficiently powerful, the net effect on business investment spending could well be positive rather than negative. Under conditions of ample underemployed resources, with unused capacity and slack final demand dominating prospects in many industries, the associated revival of overall business activity could easily stimulate investment by more than the resulting higher interest rates retard it. By contrast, when the economy is already fully employed, there is no further stimulus to total demand, and the absorption of resources 
by the government deficit unambiguously reduces the saving available to finance private investment.

In light of this sharp contrast between the effects of active deficits when the economy is fully employed and passive deficits when it is not, in considering the interaction between the U.S. Government deficit and private capital formation during the 1980 s it is important to distinguish explicitly three separate time periods: 1980-82, when the economy was deeply under-employed and there was little if any active deficit; 1983-84 (and possibly into 1985), when the economy's resources are still substantially underemployed, but with a significant active deficit; and the remainder of the decade, when (in the absence of fresh disturbances) the economy's resources will be more fully employed but under current policies there will still be a large active deficit. During 1980-82 the realized govemment deficit was not an impediment to private capital formation, because it was not in large part an active deficit and because the economy then had ample unemployed resources anyway. During 1983-84 the deficit is becoming primarily an active deficit, but it will still probably not significantly impede capital formation. At least during the early stages of the recovery, the positive effect due to the increase in the overall level of economic activity from the fiscal stimulation of the recovery will probably outweigh the negative effect due to the resulting increase in interest rates. Only during the years beginning around the middle of the decade is the government deficit likely to impair the economy's ability to finance intended capital formation.

The U.S. Government deficit in the current fiscal year and the next, therefore, is not really an object for serious concern in this context. By contrast, the concerns expressed about the deficit prospects for the 
balance of the 1980 s are well taken and important. Sustained government deficits in an approximately fully employed economy absorb private saving that could otherwise finance private investment, and during the mid to late 1980 s this absorption threatens to assume magnitudes that are unprecedented in U.S. peacetime experience. Especially since the performance of capital formation in the last decade has already been weak (and weakening), this prospect presents a major issue for public policy choice. 
II. A Strategy for Managing the Deficit

Table 4 shows the realized U.S. Government deficit for fiscal years 1980-82, together with separate deficit paths projected for fiscal years 1983-88 under three separate sets of assumptions about fiscal policy: a "current services" path, indicating the Reagan Administration's projection of the likely deficit under a continuation of current tax and spending policies (without the 1983 Social Security legislation, but with the Administration's defense program); a "Reagan budget" path, indicating the Administration's projection of the likely deficit after adoption of all of its current tax and spending proposals; and an "adjusted Reagan" path, which differs from the "Reagan budget" path only in omitting the effect of the proposed (but unlikely) "contingency tax plan."13 The table shows each deficit path both in dollar magnitudes and as percentages of gross national product. ${ }^{14}$ All three deficit paths take on the same value for 1983, because the Administration's proposals apply only to fiscal years 1984 and beyond. The "Reagan budget" and "adjusted Reagan" paths are identical through 1985, because the contingency tax plan as proposed is scheduled to take effect only beginning in fiscal year 1986.

Although these three deficit paths clearly differ, with the "Reagan budget" deficit showing the greatest relative shrinkage over time in comparison with almost none at all for the "current services" deficit, all three paths nevertheless show continuing federal deficits which, even in relation to gross national product, are well outside the historical experience reviewed in section $I$, and which persist for some time. If the problem at hand were to analyze the potential effects on capital formation of such outsized deficits for just one year or two, then the annual flow concepts used in the conventional statement of the economy's saving- 


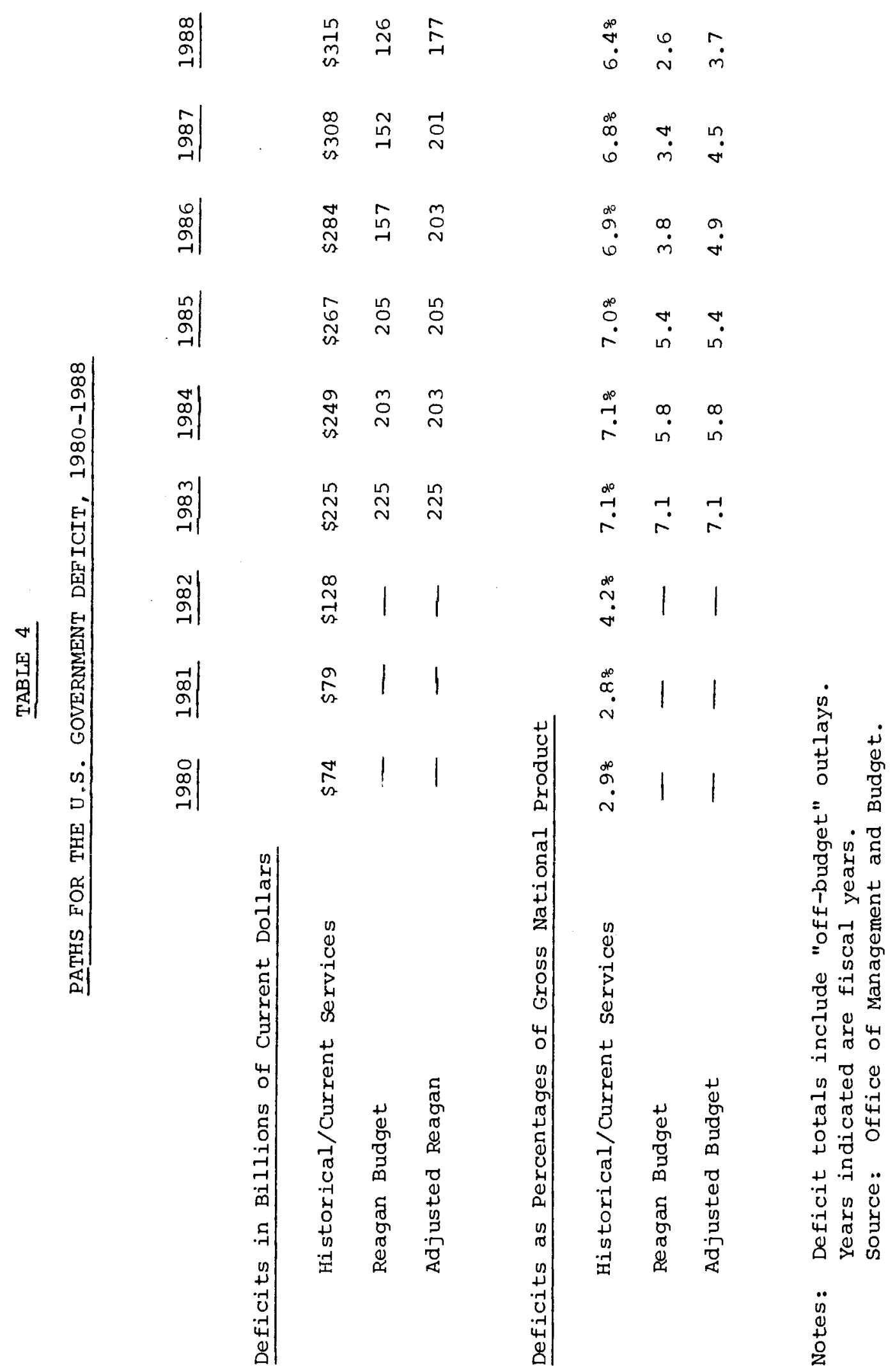


investment balance in Table 1 would be adequate. In order to assess the likely implications of each deficit path over an extended period of time, however, it is also useful to rely on some benchmark measure that goes beyond these year-by-year flows. As in most analytical models of economies that grow over time, a convenient form for such a benchmark is the relationship between an accumulating asset (or liability) stock and the flow of the economy's output as measured by gross national product.

The form of stock-flow measure that is most suitable for the purpose of analyzing the longer-run effects of government deficits is the government debt ratio, defined as the outstanding indebtedness of the U.S. Government measured as a percentage of gross national product. The reason why the govermment debt ratio is a helpful guide in this context is that a broader stock-flow relationship, of which the government debt ratio is one component, has exhibited a pronounced stability in the United States for many years. In particular, the economy's total debt ratio, including the outstanding debt not just of the federal government but of all U.S. borrowers other than financial intermediaries, ${ }^{15}$ has displayed essentially no trend (and only limited cyclical variation) throughout the post world war II period. Moreover, the stability of the U.S. economy's outstanding debt in relation to nonfinancial economic activity has not merely represented the stability of a sum of stable parts. Neither private-sector debt nor government debt has borne a stable relationship to economic activity, but their total has. Figure 1 shows the yearend indebtedness of U.S. nonfinancial borrowers, measured as percentages of fourth-quarter gross national product, for each year since the end of the Korean War, as well as the corresponding percentages for the end of the 1982 fiscal year. The top line in the figure shows the total credit market indebtedness of all U.S. nonfinancial 


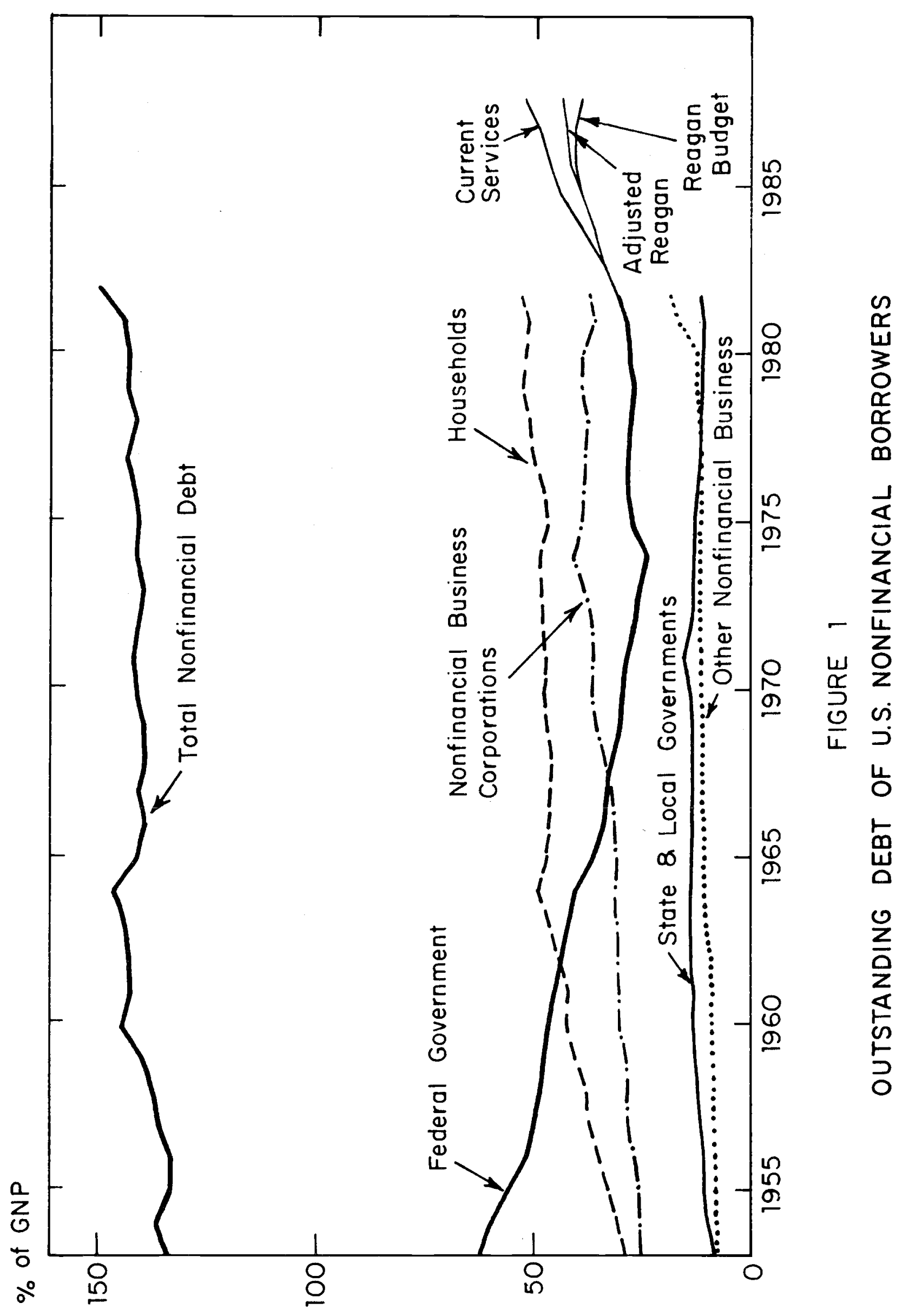


borrowers. The lines below divide this total into the respective indebtedness of each of five specific borrowing sectors: the federal government, state and local governments, nonfinancial business corporations, other nonfinancial businesses, and households.

The strong stability of the total nonfinancial debt ratio shown at the top of Figure 1 stands out plainly in contrast to the variation of the individual sector components shown below. Although the total debt ratio rose somewhat during the most recent business recession, as gross national product in the denominator weakened sharply, the experience of a similar (though less pronounced) cyclicality in prior recessions suggests no interruption of the basic long-run stability. In addition, the stability of the U.S. economy's total debt ratio is of longer standing than the thirty years plotted in Figure 1 . With the exception of a sharp rise and subsequent fall during the depression of the early 1930s (when much of the debt on record had defaulted de facto), and to a lesser extent. during world war II, the total debt ratio in the United States has been essentially constant since the early 1920s. ${ }^{16}$

By contrast, the individual components of the total debt ratio have varied in diverging ways both secularly and cyclically. In brief, the post world war II secular rise in private debt has largely mirrored a substantial decline (relative to economic activity) in public debt, while cyclical bulges in public debt issuance have mostly had their counterpart in the abatement of private borrowing. Households have almost continually increased their reliance on debt in relation to their nonfinancial activity throughout this period. Both corporations and unincorporated businesses have also issued steadily more debt, on a relative basis, except for temporary retrenchments during recession years. State and local governments 
steadily increased their relative debt issuing activity during the 1950 s and 1960s, but just as steadily reduced it during the 1970s. Finally, except only for 1975-76 and 1980-82, years marked by large deficits due to recession and its aftermath, the federal government has reduced its debt ratio in every year to date since 1953 , although this relative debt reduction has also been slower in years when even milder recessions have temporarily inflated the government's deficit (and, again, depressed gross national product in the denominator). This variation of the federal government's debt ratio provides a useful perspective on the magnitude and import of the federal deficit. During the post world War II period as a whole, the federal debt ratio has declined not just from $62.9 \%$ in 1953 but from 103.48 in 1946 . Indeed, the 24-29\% range in which the federal debt ratio fluctuated during the 1970s, and until 1982, corresponded favorably to the $27.4 \%$ value in 1918 . At the same time, the past decade has marked a departure from prior experience in an important way. The years 1975 and 1976 were the first since 1953 in which the government debt ratio rose, and the renewed decline during 1977-79, which was subsequently reversed by the recession years 1980-82, was not sufficient to reduce the ratio to its 1974 low. The federal government's debt ratio is relevant to the interaction between fiscal policy and private capital formation because, in the context of a stable economy-wide total debt ratio, it represents a useful summary measure of the net impact of federal deficits on the environment for private financing. If the government deficit is sufficiently small, or if either real economic growth or price inflation is increasing the gross national product sufficiently rapidly, then the government debt ratio will be falling - as it was, almost continuously, throughout the first 
three decades following world war II. Conversely, if the deficit is sufficiently large in relation to the economy's size and growth, then the government debt ratio will be rising - as it was during 1975-76 and 1980-82. The analytical advantage of the stock-flow relationship is that, by comparing the nominal stock of outstanding government debt to the nominal gross national product, it implicitly allows not only for economic growth but also for the much discussed (but in the end usually ignored) real capital gain that the government earns by inflating away its prior debt obligations. ${ }^{17}$ Hence the government debt ratio measure also illustrates the lack of essential importance to be attached to a precisely balanced government budget in a growing economy.

If the economy's total outstanding debt is approximately stable in relation to gross national product over time, then a sustained movement in the government debt ratio implies an offsetting movement in the aggregate private-sector debt ratio. A falling government debt ratio like that experienced during 1946-74 implies a rising private debt ratio, while a rising government debt ratio like that during 1980-83 implies a falling private debt ratio. A rising or falling private debt ratio, however, simply indicates whether the economy's private sector is increasing its outstanding debt more rapidly or more slowly than the economy's total output is growing.

The relevance in turn of a rising or falling private debt ratio for the economy's ability to undertake capital formation reflects the traditional importance in the united states of debt financing of net investment by the private sector, including both homebuilding and investment in new plant and equipment. For example, the nonfinancial corporate business sector, which typically accounts for nearly three-quarters of 
all U.S. investment in plant and equipment, relied on external debt financing for $64.3 \%$ of its total net sources of funds on average during 1956-80. ${ }^{18}$ Moreover, within this period business corporations' reliance on external debt has shown an irregular but nevertheless increasing trend. Unincorporated businesses financing new plant and equipment and households financing new homebuilding have also relied heavily, and increasingly, on borrowed sources of funds.

In the absence of a major change in financing patterns, therefore, the economy's ability to achieve a greater capital intensity - that is, to increase its capital stock in relation to total output - depends at least in part on the private sector's ability to increase its debt in relation to gross national product. Over time, however, the private sector's debt ratio moves inversely with the government debt ratio. In the end, the rise or fall of the government debt ratio is therefore likely to be an important factor shaping the relationship between growth of the capital stock and growth of the economy's total output. Figure 1 indicates the respective implications for the government debt ratio associated with each of the three projected deficit paths shown in Table 4. Just as there are large differences among the three projected deficit paths, there are also significant differences among the respective government debt ratio paths that each implies. With "current services" deficits, the government debt ratio will continue to rise steadily, reaching $51.0 \%$ of gross national product by the end of fiscal year 1988 (in comparison to 30.18 at the end of fiscal year 1982). Because the projected "Reagan budget" deficits are the smallest of the three considered, they imply the least rise in the government debt ratio. In this case the ratio will actually peak at $40.2 \%$ of gross national product at the end of fiscal year 
1987 and then decline slightly to $39.5 \%$ a year later. Without the contingency tax plan, however, the "adjusted Reagan" deficits will again imply a continuously rising government debt ratio, reaching $42.4 \%$ of gross national product by the end of the period.

What stands out in Figure 1, however, is that all three of these projected deficit paths will continue to carry the government debt ratio sharply higher, instead of returning it toward the $24.8 \%$ postwar low reached in 1974, or even stabilizing it at the 1982 level of $30.1 \%$. This projected further rise, equal to between $10 \%$ and $20 \%$ measured in terms of gross national product, will raise the government debt ratio to levels last experienced two decades or more ago. The "Reagan budget" path will return the ratio to its 1964 level, while the "current services" path will return the ratio to its 1957 level. As is apparent from Figure 1, such a sustained increase in the government debt ratio will be unprecedented in the U.S. postwar experience.

If the economy's total debt ratio remains approximately unchanged over this period, then the increase of the government debt ratio by $10-20 \%$ of gross national product implies a decline of roughly the same magnitude in the private debt ratio. ${ }^{19}$ This sustained decline in the private debt ratio will also, of course, be unprecedented in U.S. postwar experience. As of the end of the 1982 fiscal year, the debt ratios of the household and combined (corporate and unincorporated) nonfinancial business sectors were $53.0 \%$ and $54.7 \%$, respectively. A $10-20 \%$ decline, applied either to households or businesses alone or to both together, will represent a substantial re-adjustment. Because such movements will differ so sharply from prior experience, there is simply no way to say with confidence what consequences they will bring. Nevertheless, the close historical connection 
between debt financing and private investment strongly suggests that the market forces which compel the private sector to shrink its debt in relation to economic activity will hardly be conducive to private capital formation. The division of this relative debt decline between the household and business sectors will also have important implications for the composition of U.S. capital formation, along with the effect of the total decline on aggregate capital formation. Although a renewed depression of residential construction could be sufficient to reduce household mortgage borrowing by enough to absorb the entire private-sector decline, ${ }^{20}$ especially under the smaller "Reagan budget" deficits, even that extreme outcome would probably not permit any growth at all in the business sector's debt ratio - nor would sacrificing homebuilding to such an extent necessarily be desirable anyway. More probably, business debt relative to income will also have to decline in order to make room for the ballooning federal government debt.

Without the ability to raise external funds in the credit market, the business sector will largely have to forego taking advantage of the recently legislated investment incentives unless it turns massively to equity financing - an unlikely prospect in light of traditional U.S. business financing patterns. $^{21}$ put in terms of the factors confronting business decision making, the problem will be that the increased real cost of financing (and, for some companies, reduced availability) will outweigh the added attractiveness of new investment due to the large favorable tax changes. Under these conditions business will probably invest not more but less, and the U.S. economy's net capital formation rate will decline still further.

The principal conclusion of this analysis, therefore, is that either the current stance of U.S. fiscal policy or the policy stance proposed 
by the Reagan Administration is likel $_{Y}$, over the medium run, to provide a major impediment to achieving increased net capital formation and, in turn, to meeting the increased productivity growth and other more targeted economic objectives associated with increased capital formation. If fiscal policy is not to have this presumably unintended and undesirable effect, then the analysis developed here suggests, at a minimum, that it will be necessary to reduce federal government spending or raise taxes (or both) sufficiently so that the implied increase in the federal government's outstanding indebtedness over time merely keeps pace with the growth of gross national product. 22 In terms of averages for the five fiscal years 1984-88, preventing any further increase in the government debt ratio after the end of the current fiscal year would imply an annual deficit of $\$ 122$ billion, while retuming the government debt ratio to its level at the end of fiscal year 1982 would imply an annual deficit of only $\$ 74$ billion. ${ }^{23}$ By contrast, the $1984-88$ averages for the three paths shown in Table 4 are $\$ 285$ billion for the "current services" deficit, \$169 billion for the "Reagan budget" deficit, and \$198 billion for the "adjusted Reagan" deficit without the contingency tax plan.

Stabilizing the government debt ratio would therefore require very major changes even in comparison with the Reagan Administration's budget proposals, not to mention currently existing tax and spending legislation. The question that immediately arises, is what changes. This crucial issue, however, is largely a matter of value judgments, not economic analysis.

The standard trio of suggested ways to reduce the federal deficit in the medium-run future includes cutting entitlement program benefits, slowing the scheduled acceleration in defense spending, and 
eliminating either the reduction in individual income tax rates which took effect in 1983 or the indexation of the tax code scheduled to take effect in 1985. The magnitude of the change involved in reducing the average 1984-88 deficit to the \$74-122 billion range is such, however, that no one among these three steps would by itself be sufficient. Table 5 shows a decomposition of the U.S. Government budget position (including offbudget outlays) into components roughly corresponding to these three policy options, plus an additional expenditure category for net interest payments, measured throughout as percentages of gross national product. The table applies this decomposition to the actual outcomes for fiscal years 1979 (the last in which the federal deficit did not exceed $2 \%$ of gross national product) and 1982 , as well as to the projected outcomes for fiscal year 1983 and, on an annual average basis, each of the three projected deficit paths for 1984-88 shown in Table 4. What emerges clearly from this decomposition is that, at least in comparison with 1979, substantially all of the increase in the projected deficit for the 1980 s is due to a reduction in revenues and an increase in defense spending in relation to gross national product. ${ }^{24}$ The Economic Recovery Tax Act of 1981 (diminished in part by the Tax Equity and Fiscal Responsibility Act of 1982 ) will reduce total revenues by about $1 \%$ of gross national product in 1984-88, in comparison with 1979, while the scheduled military program will raise defense spending by nearly $3 \%$. The adjustments in both of these trends proposed by the Reagan Administration, even including the contingency tax plan, are relatively small. By contrast, all other federal expenditures (other than net interest) will return to their 1979 level in relation to gross national product under current legislation, and will decline by a further $1 \%$ under the Administration's 


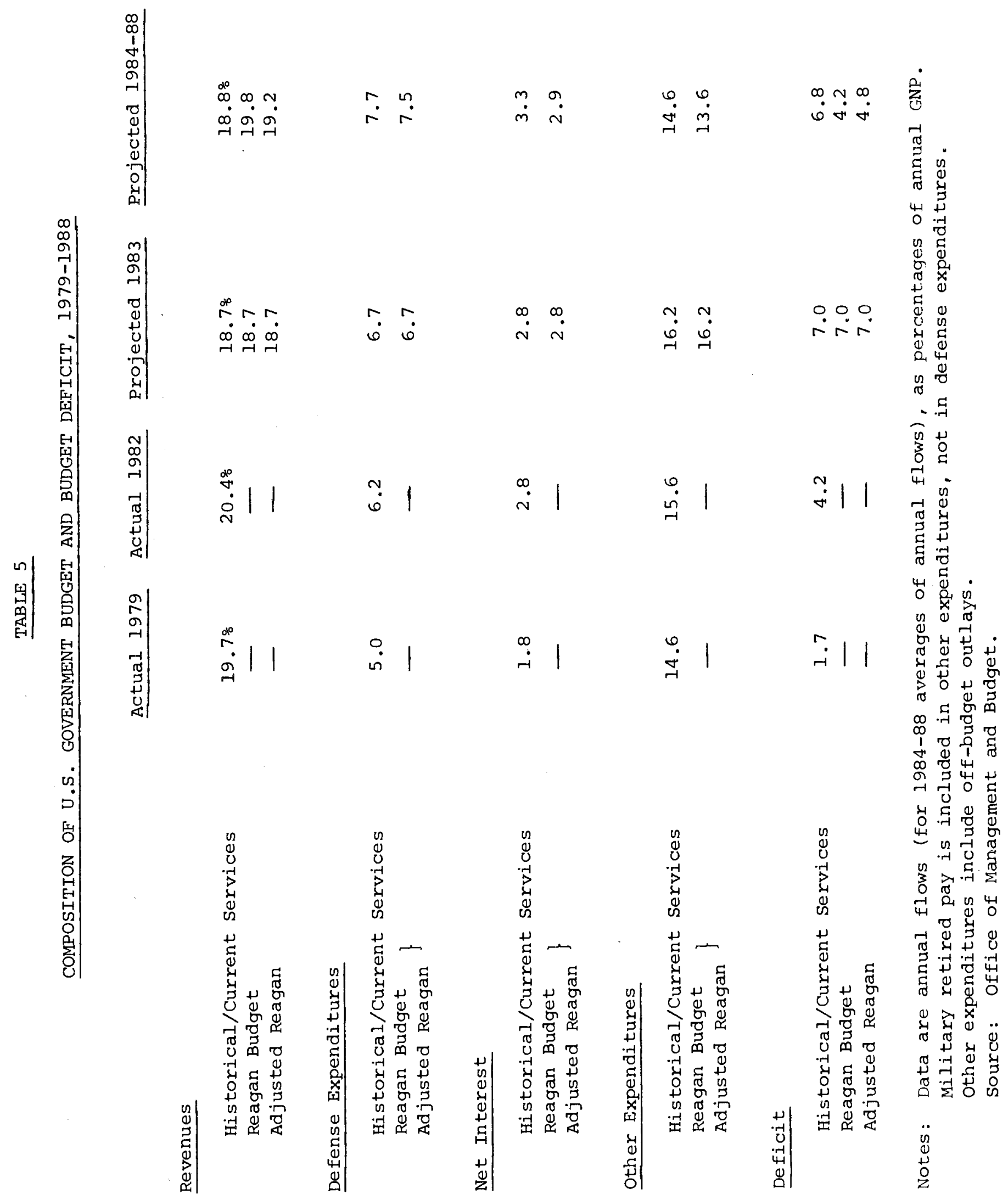


proposals. $^{25}$ Such comparisons can never serve to resolve issues that depend so heavily on value judgments, but they at least serve to place in perspective the nature of the policy choices to be made.

Difficult as it would be to reduce the federal deficit to \$74-122 billion on average during 1984-88, even this magnitude of budgetary change would still provide not a falling government debt ratio as in the earlier postwar decades but merely a stable government debt ratio as in the 1970s - hardly an enviable era for federal budgets, corporate finance, or net capital formation. Achieving a more capital intensive economic technology overall - that is, a greater ratio of physical capital to output - would more ljkely require over time a rising business debt ratio, and that in turn would require federal budget deficits small enough to allow the government debt ratio to begin to decline once again. Nevertheless, for the medium-run future that more ambitious goal now appears well beyond reach. 
III. The Composition of Government Spending and Liabilities

The analysis in sections I and II focuses on the implications for private capital formation of fiscal policy at the level of the overall federal budget deficit. These aggregate aspects of fiscal policy probably capture the most powerful way in which government budget actions affect private capital formation, but it is hardly the only way. The composition of many of the major budget categories can importantly affect capital formation too. Moreover, in recent years several budget categories have undergone major composition changes that could significantly matter in this regard. Two of these, the composition of the government's spending and of its liabilities, merit particular attention here. ${ }^{26}$

\section{A. Composition of Expenditures}

Table 6 shows the ownership composition of the net stock of fixed nonresidential capital in the United States as of yearend 1981. The U.S. Government holds only one-tenth of the nation's capital stock, and slightly more than half of that consists of military installations and equipment. In comparison to the private sector, or to state and local governments, the federal government's participation in this context is small. Nevertheless, the economy's productivity does not depend on private capital alone, and "infrastructure" investment of the kind typically put in place by government programs and subsequently held under government ownership can make an important contribution in this regard. ${ }^{27}$ In addition, a substantial amount of the investment activities undertaken by state and local governments rely heavily for financing on grants from the federal government. In both senses the composition of federal government spending determines another potentially important aspect of the economy's total capital formation. 
OWNERSHIP OF NET STOCK OF U.S. NONRESIDENTIAL FIXED CAPITAL, 1981

Private Sector

Corporate Business

Other

State and Local Governments

Federal Government

Military

Other
$\$ 2,849$

2,052

797

1,813

578

293

285

5,241

Total

Notes: Values in billions of dollars. Detail may not add to total because of rounding. Government totals include government-owned enterprises. Private-sector total excludes consumer-owned durable goods. Source: U.S. Department of Commerce. 
Table 7 presents a summary of the U.S. Government's fixed nonresidential investment spending, including both direct spending on military and other fixed capital as well as grants to state and local governments for fixed investment purposes. The table shows these investment flows in dollar magnitudes and in relation to both total federal spending and total privatesector gross investment in plant and equipment, as actually realized for every fifth fiscal year since 1955 and as proposed by the Reagan Administration for the 1984 fiscal year. Direct federal government investment spending for purposes other than military has remained small in relative terms throughout this period, while investment-purpose grants to state and local governments have been somewhat larger, and have steadily risen in comparison to the private investment total. Both elements represent contributions to the economic "infrastructure". 28 Investment in military capital has always represented at least half of all federal investment spending, although there has been great variation over this period. Except for a bulge in the late 1960 s associated with the viet Nam War, military investment as a share of total federal spending declined from the mid 1950 s through the 1970s. The increase proposed by the Reagan Administration for the 1984 fiscal year, however, will reverse part of this trend.

As a result of the irregular pattern of government investment spending, together with the small post world war II base, the growth of the nonmilitary federal government capital stock in the United states has not slowed in recent years in parallel with the slower growth of the private capital stock. Table 8 shows the respective constant-dollar growth rates of the net capital stock held by the private sector, by state and local governments, and by the federal government (including military and nonmilitary capital separately), by five-year averages for $1956-80$ and 


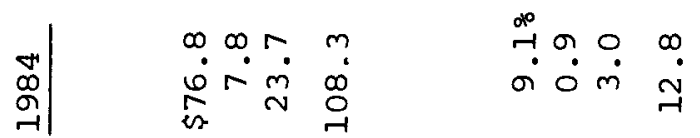

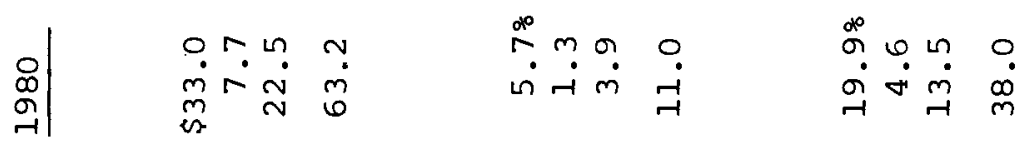

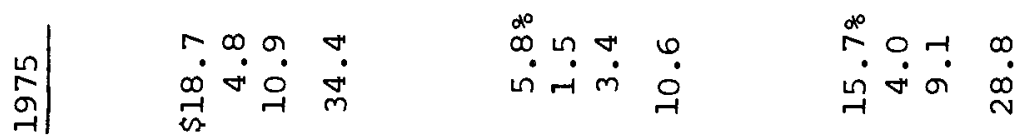

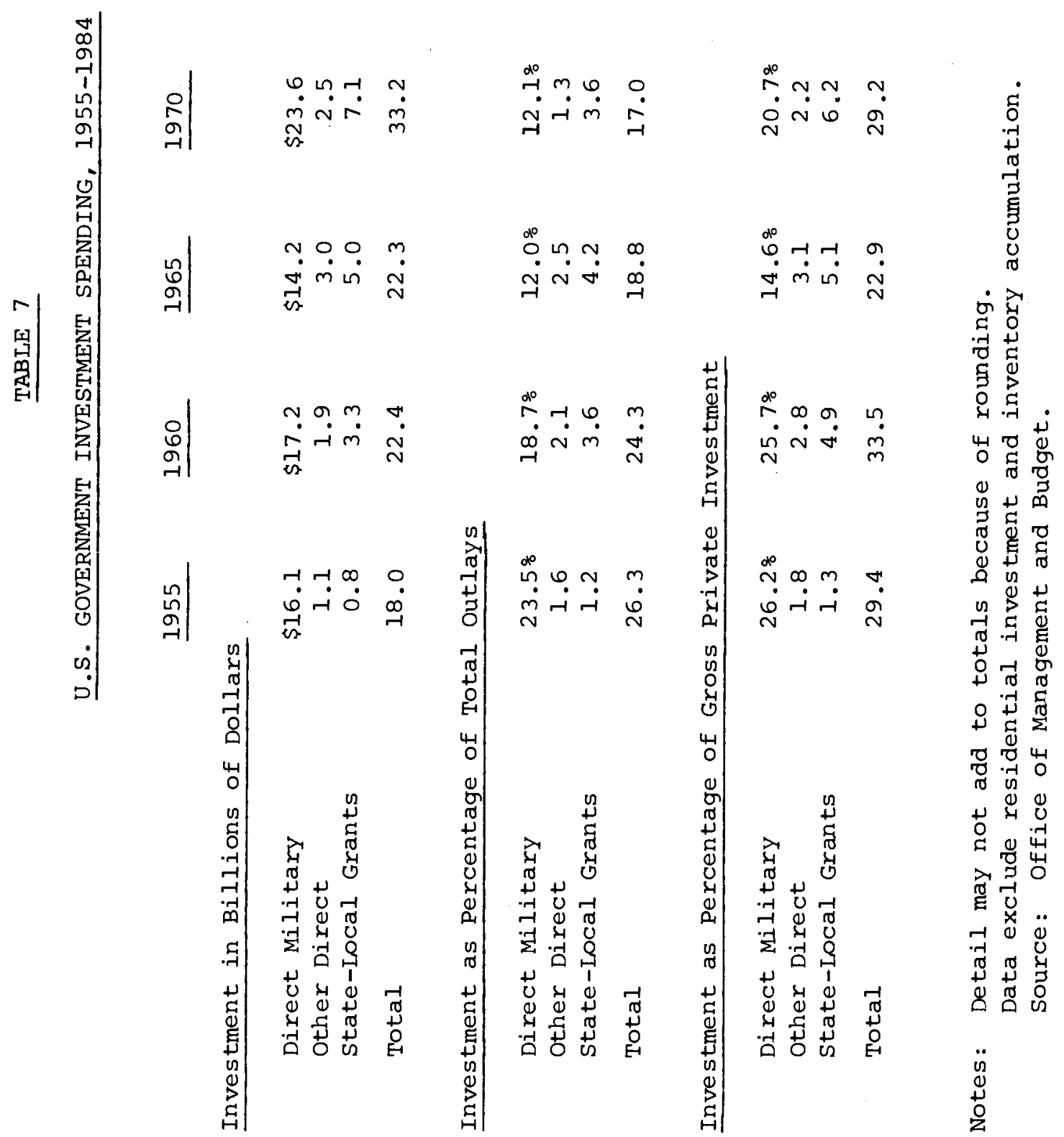




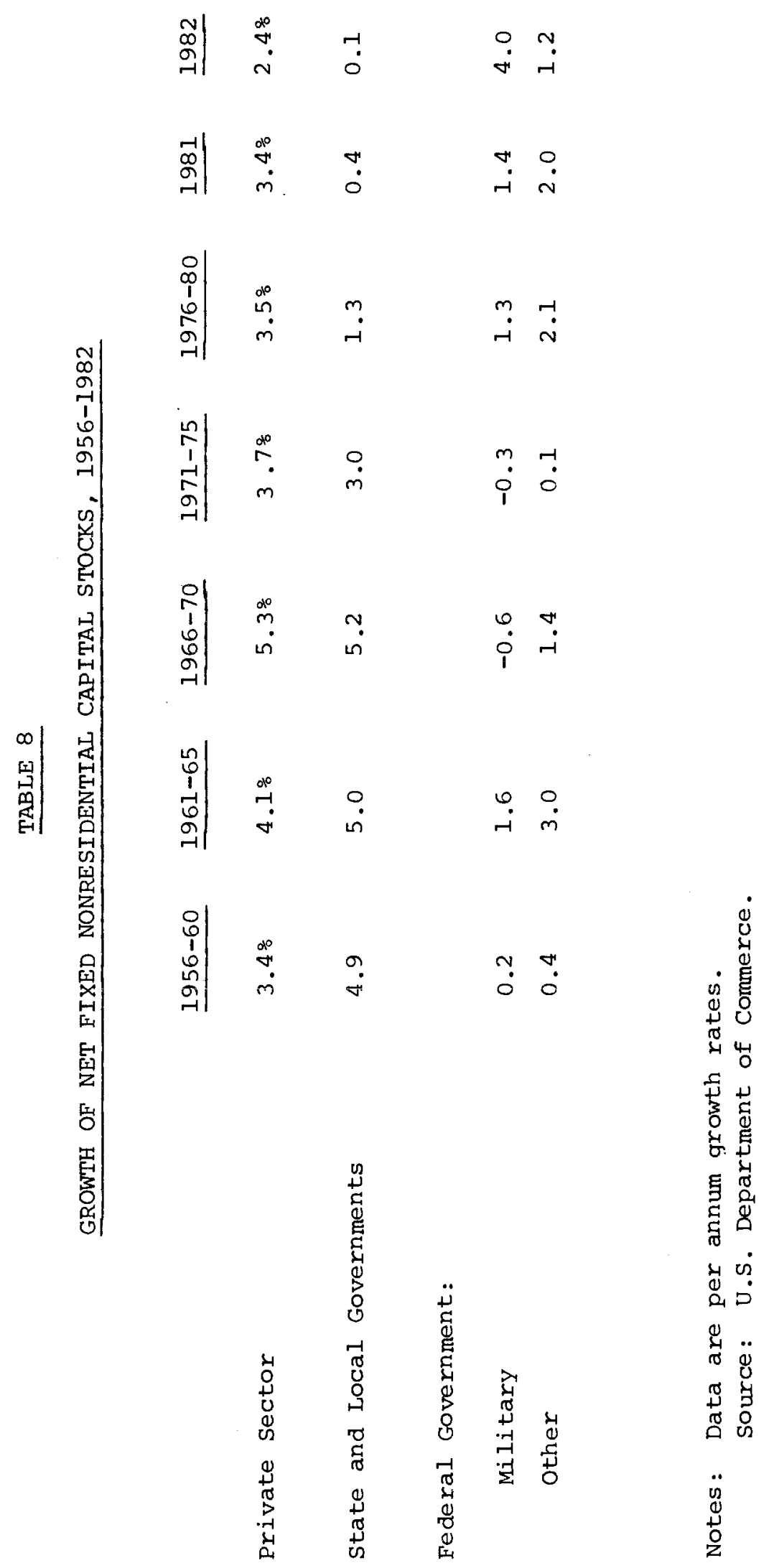


for 1981 and 1982 individually. Because of the decline in the school-age population, and the completion of major investments in roads, sewers and hospitals, the net capital stock owned by state and local governments has slowed its growth almost to a standstill since the mid 1970s. By contrast, during the late 1970 s and through 1981, the federal government's net stock of nonmilitary capital grew at a more rapid rate than at any time since the early 1960s.

Nevertheless, at no time during the past quarter century - even during the late 1970 - has the federal government's net stock of nonmilitary capital grown as rapidly as the private capital stock. In addition, at no time during this period (except for isolated recession years) has the federal nonmilitary capital stock grown as rapidly as gross national product. Although the contribution of publicly owned capital to growth and productivity is a subject about which little is known with any quantitative precision, both the government and the private sector can add to the economy's overall capital intensity. Instead, the U.S. economy has made do each year with less federal government capital in relation to total output. Policy changes to increase the economy's government-capital intensity, or at the least to prevent it from declining further, would involve significant changes in the mix of federal government spending between investment and current outlays.

\section{B. Composition of Liabilities}

The outstanding debt of the U.S. Government will at least double during the decade of the 1980s, even on the most optimistic plausible assumptions about fiscal policy, economic performance, and consequent budget deficits. Under the "current services" deficit path shown in Table 4 , 
the government's outstanding debt will more nearly triple. In the context of this large and rapidly growing stock of government liabilities to be held by investors, the government's choice of the composition of its liabilities - that is, federal debt management - can also have important implications for private capital formation.

The basic reason why federal debt management can affect such seemingly distant aspects of economic activity as business investment is that neither borrowers nor lenders in financial markets are indifferent to the maturity of the debt securities that they respectively issue and hold. In order to reduce risks associated with the cost and availability of future refinancing, businesses funding investments in long-lived plant and equipment typically seek to finance those investments by issuing longterm debt. That preference would not matter if lenders were as willing to advance funds at long term as at short term, but in fact most lenders appear to prefer to hold short-term securities. Indeed, after their recent experience with rapid inflation, high interest rates and volatile bond prices, many traditional participants in the U.S. long-term markets are now reluctant to commit funds to extended maturities, turning instead to short-term instruments and other securities with more stable values. As a result, businesses seeking to issue bonds to finance fixed capital formation have found long-term financing more costly and, in many cases, less available.

When the U.S. Government issues large volumes of long-term bonds, it further raises the cost, and further reduces the availability, of longterm financing for business and other private-sector borrowers. Discouraged by an unreceptive bond market, a business seeking to finance a new plant, or new equipment to modernize an old one, can respond in either of two 
ways. One is simply to cancel or curtail its planned investment. The other is to go ahead with its investment on the basis of short-term financing, hoping to fund out its liabilities in the future but for the present accepting the deterioration in its financial structure. The experience of the U.S. economy during recent years has exhibited both of these patterns. Not only has net fixed investment declined, but business has increasingly financed what investment it has undertaken at short term, so that many corporations' balance sheets have weakened significantly. If the government instead issued short-term securities, it would free the limited supply of long-term lending to go to borrowers in the private sector. In some cases the result would be additional private capital formation, while in others it would be a sounder financial structure. Either way, reliance on short-term financing in federal debt management would promote a more productive and financially secure economy.

During most of the post World War II period, the U.S. Government managed its debt in a manner consistent with leaving as much as possible of the market's supply of long-term lending for private borrowers. When the war ended, the outstanding marketable interest-bearing debt held by private investors consisted mostly of long-term securities. Over the next three decades, the Treasury typically refinanced maturing issues and financed new budget deficits by relying on shorter-term securities, so that the average maturity fell from almost ten years at yearend 1945 to just under two and one-half years by yearend 1975. The percentage of the outstanding debt maturing within one year more than doubled over these three decades, while the percentage maturing in one to five years also increased, and the percentage maturing in over five years declined dramatically. Table 9 documents this experience since 1955. 


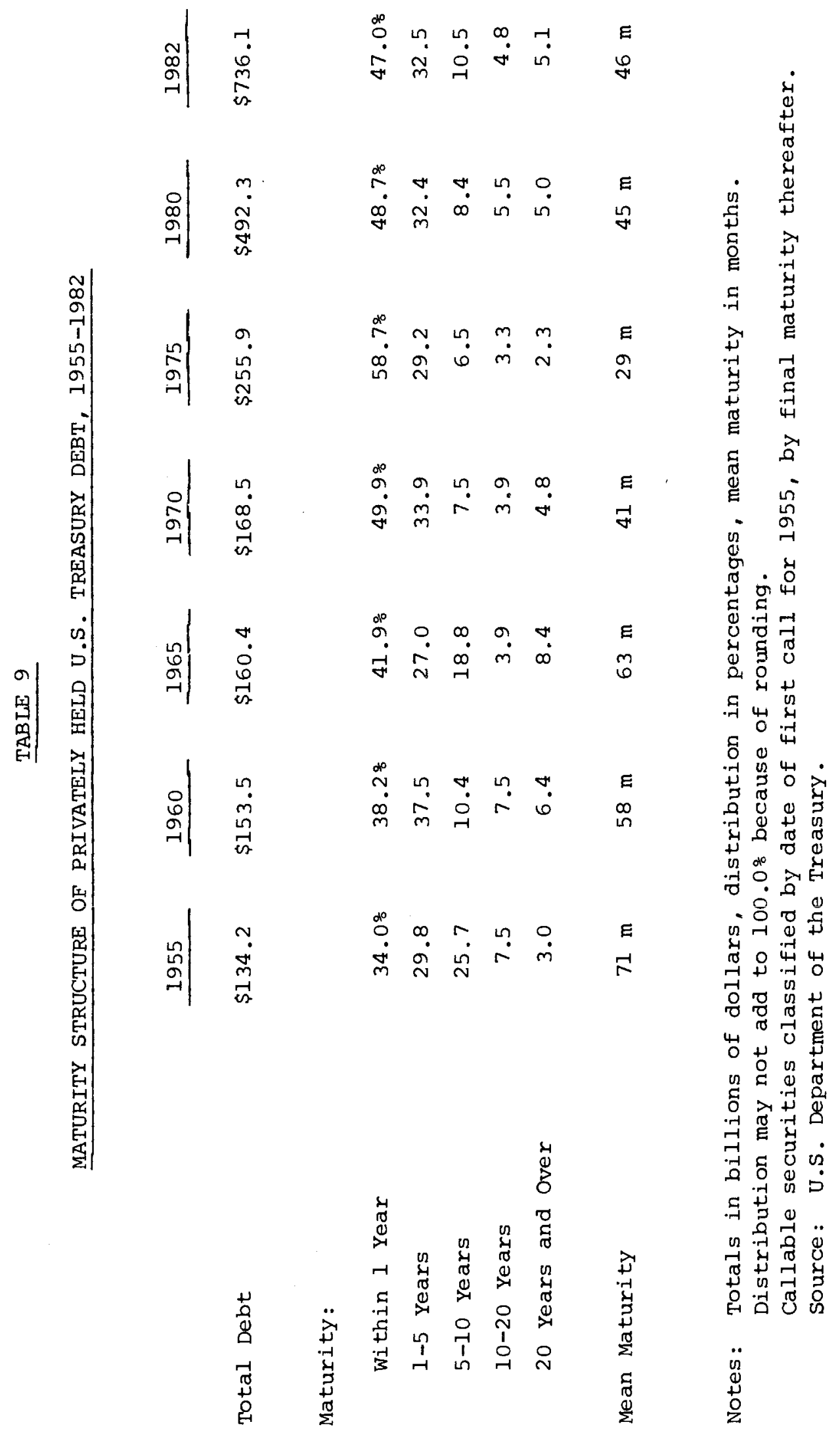


Since 1975, however, the federal government has pursued exactly the opposite policy, placing sufficient reliance on long-term securities to raise the overall average maturity outstanding back to four years by the end of 1981. Except for a Congressional delay in increasing the legal limitation on long-term financing at current interest rates, the average maturity would have been even greater by the end of 1982 . This new debt management policy has involved a regular cycle of short- and medium-term note issues, together with a series of new thirty-year bonds. The outstanding U.S. Government debt maturing in more than ten years grew from only $\$ 14$ billion at yearend 1975 to $\$ 73$ billion at yearend 1982 . The net increase in outstanding debt maturing in more than ten years - that is, gross new issues with more than ten years initial maturity, less purchases by U.S. Government trust accounts, less the amount of outstanding issues moving from over to under ten years maturity by the passage of time was \$14 billion in 1981 alone and, despite the legislative delay, another $\$ 7$ billion in 1982. In comparison, the entire net volume of corporate bonds issued each year by U.S. firms in nonfinancial lines of business was only $\$ 24$ billion in 1981 and $\$ 22$ billion in 1982 , and much of those totals consisted of medium-term issues.

With its post-1975 debt management policy, therefore, the U.S. Government has been lengthening its outstanding debt just as rapidly as the policy of the previous three decades shortened the debt. In doing so, it has been pre-empting for the government an historically unprecedented (at least in peace time) share of the economy's long-term borrowing and lending. The possible offsetting advantages associated with the post-1975 debt management policy have included whatever effects the development once again of a large and highly active trading market 
for long-term U.S. Government securities may have had in stimulating the market for long-term corporate securities, and hence making them also more liquid. Both the increased size of the government's outstanding long-term debt and the regular flow of new issues may have contributed in this regard. Nevertheless, this active trading market is now in place, and any further technical gains that would follow from a continued average lengthening of the federal debt are therefore problematical. By contrast, the economic impact in terms of reduced private capital formation (and weaker balance sheets) remains.

The effects of federal debt management policy on capital formation, on patterns of corporate financing, and even on the overall level of nonfinancial economic activity, can be substantial. Empirical evidence suggests that debt management actions of a magnitude comparable to the recent changes in the U.S. Government's debt management policy have sizeable effects both in the financial markets and more broadly. In particular, the evidence suggests that a federal debt management policy emphasizing short-instead of long-term debt issues would lower yields on both government and corporate long-term bonds and on corporate equities, would raise yields on most short-term securities, and would stimulate output and spending. 29 The stimulus to spending would be disproportionately concentrated in fixed investment, so that such a policy would not only increase the economy's output but shift its composition toward additional private capital formation. Because the induced change in the pattern of corporate financing from short- to long-term borrowing (in response to the change in relative interest rates) would be larger than the induced increase in investment spending), such a policy would also lead to an improvement in the structure of business balance sheets. 
The federal government's management of the composition of its liabilities the refore constitutes still another dimension of policy choice that can either foster or impede U.S. capital formation. As is the case for the composition of federal spending, policies that would enhance the economy's net capital formation rate would require significant changes from the policies pursued in recent years. 


\section{Summary of Conclusions}

The widespread public concern that the U.S. Government's budget deficit will retard the economy's capital formation in the second half of the $1980 \mathrm{~s}$ is warranted. In the absence of major policy changes, federal government deficits will probably constitute a serious impediment to any increase in the U.S. economy's net investment rate, and may even depress the investment rate still further, during the latter 1980s.

The source of this effect will be the continuing absorption, by the federal government, of a large share of the nation's net saving. This absorption is not a problem when the economy's resources are unutilized, but it is a potentially serious problem at or near full employment. Saving used to finance a government deficit in those circumstances is not available to finance private-sector capital formation. Under current policies, increased government absorption of saving in the 1980s will easily outstrip any plausible increases in the saving rate associated with recently implemented tax changes or other factors. As a result, the share of the nation's output devoted to net capital formation will at best remain low.

A useful summary measure of the impact over time of government deficits on the financing of capital formation is the government's outstanding debt as a ratio to gross national product. The U.S. Government's debt ratio declined steadily from the end of world war II until the early 1970s. The government debt ratio was then stable, on average, from the early $1970 \mathrm{~s}$ until the early 1980s. It is now rising sharply and, under either current legislation or the budget policies proposed by the Reagan Administration, it will continue to do so. This sustained upward movement of the government debt ratio will be unprecedented in U.S. experience 
since World War II.

The reason why a rising government debt ratio bears negative implications for private capital formation is that government debt and private-sector debt have historically moved inversely in relation to gross national product in the United States. A rising government debt ratio over time therefore implies a sustained contraction of private debt relative to the size of the economy. If market forces compel the private sector to reduce its debt position, however, its ability to finance increased capital formation will be dubious at best.

An alternative fiscal policy that would at least stabilize the government debt ratio over the medium-run future would require limiting the average federal budget deficit during fiscal years 1984-88 to about one-third of that likely under current tax and spending legislation, or about one-half of that proposed by the Reagan Administration. Even then, however, a stable rather than declining government debt ratio would only replicate during the 1980s the experience of the 1970s. A declining government debt ratio (and rising private debt ratio), as during the first three decades after World War II, is probably well beyond reach.

In addition to these implications of the overall stance of fiscal policy in the aggregate, the composition of the U.S. Government's spending also shapes prospects for capital formation, as does the composition of the government's liabilities. Recent developments have borne negative implications for capital formation in both of these respects as well as in the aggregate. The federal government's direct investment in nonmilitary fixed capital is not keeping pace with the economy's growth, nor are federal grants to support capital investment by state and local governments. At the same time, the recent emphasis on long-term borrowing in financing 
the federal deficit has increased, rather than reduced, the extent to which government borrowing interferes with the financing of private capital formation. Appropriate changes both in federal spending priorities and in federal debt management would favorably affect U.S. capital formation, although in neither case would the likely effects be as large or as important as a major reduction of the average deficit over time to the level consistent with maintaining a stable government debt ratio. 
* This paper was prepared for the Wharton/Reliance Symposium on "Removing Obstacles to Economic Growth" held at the University of Pennsylvania, Philadelphia, May 1983. The paper draws in part on my earlier research, and I am grateful to the National Bureau of Economic Research, the National Science Foundation and the Alfred P. Sloan Foundation for support of that research. I am also grateful to Arturo Estrella for research assistance; to Gerald Silverstein for supplying unpublished U.S. Department of Commerce data; and to James Duesenberry, John Lintner and Michael wachter for helpful comments on an earlier draft.

1. Data are from the U.S. Department of Commerce (Bureau of Economic Analysis) and the U.S. Department of Labor (Bureau of Labor Statistics).

2. See Denison (1979) and Kendrick (1979) for comprehensive treatments of factors contributing to changes in U.S. economic growth and productivity trends. For more specific (and conflicting) assessments of the role of fixed capital, see Baily (1981) and Bosworth (1982).

3. This trend has already slowed, however, and it will probably turm around during the 1980s. One reason is the slower growth, and in some cases the contraction, of public school systems associated with the declining school-age population. Another is the sharp rise in general government operating deficits associated with tax limitations or reductions in many states. See Kotlikoff and Smith (1983) for a summary of the funding status of state and local government pensions.

4. The division of gross plant and equipment investment into respective components representing net investment and depreciation depends, of course, on an accurate estimate of the corresponding depreciation rate. In practice, this estimation hinges crucially on issues of inflation accounting. See, for example, Shoven and Bulow (1975).

5. In 1955 the economy's gross stock of fixed nonresidential private capital, measured on a constant-dollar basis, consisted of $56.7 \%$ structures and 43.3\% equipment. In 1981 the corresponding composition was $48.3 \%$ structures and $51.7 \%$ equipment. (Data, here as in the following paragraph, are from the U.S. Department of Commerce, Bureau of Economic Analysis.)

6. For comparison, the deficit in the 1982 fiscal year was $4.2 \%$ of gross national product. (The data in Table 1 apply to calendar rather than fiscal years.) Estimates attributed to the Administration, both here and below, are from the office of Management and Budget.

7. On the basis of a priori considerations alone, even the sign of the saving response to interest rate levels is indeterminate; see, for example, Feldstein (1978). For examples of the conflicting conclusions reached in the corresponding empirical literature, see Boskin (1978), How rey and Hymans (1978), and Summers (1981). 
8. It is always possible to argue that, even in this context, private investment would be greater if the government ran a high-employment surplus, but such a claim presumably ignores any accelerator effects due to the still further depression of aggregate demand. For evidence on accelerator versus interest-rate determinants of investment, see Kopcke (1977) and Berson and Roley (1981).

9. In addition to the claim on resources represented by the financing of its own deficit, the government also pre-empts resources when it guarantees the debt of private borrowers. The reason is simply that government guaranteed debt, like the government's own debt, takes precedence in lenders' portfolios over potentially defaultable privaté debt. In addition to the spending indicated in Table 3, in the 1982 fiscal year the U.S. Government extended $\$ 47.6$ billion in direct loans and guaranteed a further $\$ 53.7$ billion of private loans. (Data are from the U.S. Office of Management and Budget.) For an analysis of the economic effects of federal credit programs, see penner and Silber (1973).

10. Contrary to widespread popular belief, an "accommodative" monetary policy in this sense does not mean that the central bank purchases all debt issued by the federal government. In a fractional reserve banking system, the great bulk of the "monetization" of the deficit is done by the commercial banking system. The monetary authority purchases just enough of the government debt to provide the necessary reserves.

11. In this case private investment could even be higher as a result of the monetized deficit if the (temporary) increase in real money balances also reduced interest rates.

12. See, for example, Blinder and solow (1973) and Friedman (1978).

13. Data are from the U.S. Office of Management and Budget. The reason for omitting the "contingency tax plan" is that, as of the time of writing, it appears to have little or no prospect of passage by Congress. Moreover, even the Administration's support for its own proposal seems questionable.

14. The gross national product values used are those actually realized for 1980-82 and those projected by the Administration for 1983-88.

15. The reason for excluding the debt of financial intermediaries is simply to avoid double counting.

16. See Friedman (1980) for a discussion of the behavior of the total debt ratio during 1918-78. Friedman (1982) sets out several behavioral hypotheses that could explain this phenomenon.

17. This capital gain is a key part of the process by which inflation transfers resources form the private sector to the government, as described in section I. For a calculation of this capital gain during the post world war II period, see Eisner and piepers (forthcoming). 
18. The remaining net sources were equity issues $(5.28)$ and retained domestic and foreign earnings net of inventory valuation adjustments (30.5\%). Net sources of funds in turn accounted for $56.9 \%$ of nonfinancial corporations' total sources of funds, with capital consumption allowances contributing 43.1\%. (Data are from the Board of Governors of the Federal Reserve System.) For a review of nonfinancial corporate business financing patterns in the United States, see Friedman (1981a).

19. It is at least possible, of course, that some fundamental change in economic behavior could cause the economy's total debt ratio to rise more than just cyclically, thereby enabling the private sector debt ratio to remain steady or even rise despite a rising government debt ratio. In light of the stability of the total debt ratio documented in Friedman $(1980,1982)$, however, it is not clear what would induce such a change during the 1980s; see also the analysis of public and private debt ratio interactions in Friedman (1981b). The argument here also rests on the assumption that state and local governments will continue to maintain about the same debt ratio as in recent years.

20. Mortgage debt typically constitutes nearly two-thirds of all debt owed by U.S. households.

21. It is also possible that an increase in equity financing could make up for the reduced business reliance on debt funds, and thereby facilitate an increased capital formation rate despite a declining business debt ratio. Indeed, during the first half of 1983, net new issues of equities by nonfinancial business corporations averaged a record $\$ 34.0$ billion per annum, equal to two-fifths of their total issues of equity plus credit market debt instruments, and well above the previous record of $\$ 12.9$ billion set in 1980. (Data are from the Board of Governors of the Federal Reserve System.) This surge was probably a result of the large increase in equity prices in the immediately prior half-year, however. In light of historical patterns of U.S. corporate financing, even the continuation of net equity issues at this pace - much less at a sufficient pace to make up the difference between a rising and a falling business debt ratio appears unlikely.

22. Tobin (1982) has also advanced an analysis along these lines.

23. These calculations again rely on the Administration's estimates of nominal income.

24. Different benchmark dates would yield different comparisons, of course; see, for example, footnote 25 below.

25. In comparison to the early 1960s, however, other expenditures relative to income will remain sharply higher. Similarly, in comparison to the early 1960s, military expenditures have shrunk relative to income. 
26. A third and perhaps even more obvious example, which lies beyond the scope of this paper, is the composition of government revenues. See the papers by Auerbach, Hausman, and Shoven in this volume.

27. Investment in human capital is also an important determinant of the economy's productivity; this subject lies beyond the scope of this paper, however.

28. Of the $\$ 285$ billion of federally owned net nonresidential capital stock (other than military) indicated in Table $6, \$ 231$ billion, or $81 \%$ consisted of structures. Similarly, of the $\$ 1,813$ billion indicated for state and local governments, $\$ 1,726$ billion, or $95 \%$, consisted of structures. By contrast, of the $\$ 2,849$ billion indicated for the private sector, only $\$ 1,525$, or 548 , consisted of structures.

29. See Friedman (1981c) and Roley (1982). 
References

Baily, Martin Neil. "The Productivity Growth Slowdown and Capital Accumulation." American Economic Review, LXXI (May, 1981), 326-331.

Berson, David W., and Roley, V. Vance. "Business Fixed Investment in the 1980s: Prospective Needs and Policy Alternatives." Federal Reserve Bank of Kansas City, Economic Review (February, 1981), 3-16.

Blinder, Alan S., and Solow, Robert M. "Does Fiscal Policy Matter?" Journal of Public Economics, II (April, 1973), 319-337.

Boskin, Michael J. "Taxation, Saving and the Rate of Interest." Journal of Political Economy, LXXXVI (April, 1978), S3-S27.

Bosworth', Barry. "Capital Formation and Economic Growth." Brookings Papers on Economic Activity (No. 2, 1982), 273-317.

Denison, Edward F. Accounting for Slower Economic Growth. Washington: The Brookings Institution, 1979 .

Eisner, Robert, and Piepers, Paul J. "A New View of the Federal Debt and Budget Deficits." American Economic Review, forthcoming.

Feldstein, Martin. "The Rate of Return, Taxation and Personal Saving." Economic Journal, LXXXVIII (September, 1978), 482-487.

Friedman, Benjamin M. "Crowding out or Crowding In? The Economic Consequences of Financing Government Deficits." Brookings Papers on Economic Activity (No. 3, 1978), 593-641.

Friedman, Benjamin M. "Postwar Changes in the American Financial Markets." Feldstein, ed., The American Economy in Transition. Chicago: University of Chicago Press, 1980.

Friedman, Benjamin M. "Financing Capital Formation in the 1980s: Issues for Public Policy." Wachter and wachter, eds., Toward a New U.S. Industrial policy? Philadelphia: university of Pennsylvania Press, 1981a.

Friedman, Benjamin M. "The Relative Stability of Money and Credit 'Velocities' in the United States." Mimeo, National Bureau of Economic Research, $1981 b$.

Friedman, Benjamin M. "Debt Management Policy, Interest Rates, and Economic Activity." Mimeo, National Bureau of Economic Research, 1981c.

Friedman, Benjamin M. "Debt and Economic Activity in the United States." Friedman, ed., The Changing Roles of Debt and Equity in Financing U.S. Capital Formation. Chicago: University of Chicago Press, 1982 . 
Howrey, E. Philip, and Hymans, Saul H. "The Measurement and Determination of Loanable-Funds Saving." Brookings Papers on Economic Activity (No. 3, 1978), 655-685.

Kendrick, John W. "Productivity Trends and The Recent slowdown: Historical Perspective, Causal Factors and Policy Options." Fellner, ed., Contemporary Economic Problems 1979. Washington: American Enterprise Institute, 1979.

Kopcke, Richard $W$. "The Behavior of Investment Spending During the Recession and Recovery, 1973-76." New England Economic Review (November/ December, 1977), 5-41.

Kotlikoff, Laurence, and Smith, Daniel. Pensions in the American Economy. Chicago: University of Chicago Press, 1983.

Penner, Rudolph G., and Silber, William L. "The Interaction Between Federal Credit Programs and the Impact on the Allocation of Credit." American Economic Review, LXIII (December, 1973), 838-852.

Roley, V. Vance. "The Effect of Federal Debt Management Policy on Corporate Bond and Equity Yields." Quarterly Journal of Economics, XCVII (November, 1982), 645-668.

Shoven, John B., and Bulow, Jeremy I. "Inflation Accounting and Nonfinancial Corporate Profits: Physical Assets." Brookings Papers on Economic Activity (No. 3, 1975), 557-598.

Summers, Lawrence H. "Capital Income Taxation and Accumulation in a Life Cycle Growth Model." American Economic Review, LXXI (September, 1981), 533-544.

Tobin, James. "Budget Deficits, Federal Debt, and Inflation in Short and Long Runs." Toward a Reconstruction of Federal Budgeting. New York: The Conference Board, 1982. 